\title{
Kartu Ragam Gerak Tari Pendet Berbasis 3 Bahasa sebagai Stimulasi Kinestetik Anak Tuna Grahita
}

\author{
Arina Restian ${ }^{\mathrm{a}, 1}$, Alfiatussa'adah $^{\mathrm{b}, 2}$ \\ ab Universitas Muhammadiyah Malang, Jalan Raya Tlogomas 246, Malang, Indonesia, 65144 \\ ${ }^{1}$ arina.poenya@gmail.com*; ${ }^{2}$ alfiatussaadah49@gmail.com
}

\begin{tabular}{l}
\hline INFO ARTIKEL \\
\hline Sejarah Artikel: \\
Diterima: $21-08-2019$ \\
Direvisi: $18-11-2019$ \\
Disetujui: $18-11-2019$
\end{tabular}

Kata Kunci:

anak tuna grahita

kartu gerak tari pendet

stimulasi kinestetik

\begin{abstract}
ABSTRAK
Penelitian ini bertujuan untuk melatih kecerdasan kinestetik siswa tuna grahita di SDN Pandanwangi 3 Malang. Hal ini dilakukan dengan memberikan stimulasi kinestetik berupa gerakan-gerakan dasar tari pendet yang dijelaskan melalui media kartu ragam gerak tari pendet. Dalam media ini digunakan 3 bahasa sebagai bahasa pengantarnya, yaitu bahasa Indonesia, bahasa Inggris, dan bahasa Thailand. Penelitian menggunakan model ADDIE. Sumber data penelitian adalah siswa tuna grahita di SDN Pandawangi 3 Malang, GPK, validator ahli materi dan media. Penelitian dilakukan 2 kali pada semester genap 2018/2019. Penelitian dilakukan dalam 5 tahapan, yaitu analisis, desain, pengembangan, implementasi, dan evaluasi. Hasil penelitian menunjukan (1) telah dilakukan implementasi pengembangan kartu ragam gerak tari pendet berbasis 3 bahasa dengan cara melakukan proses belajar mengajar dan penerapan 10 gerakan dasar tari pendet yang terdapat di dalam kartu ragam gerak tari pendet, (2) keefektifan pengembangan kartu ragam gerak tari pendet berbasis 3 bahasa sebagai stimulasi kinestetik pada anak tuna grahita di SDN Pandanwangi 3 Malang harus diterapkan. Hal ini ditunjukan dengan uji keefektifan hasil belajar dengan presentase $65 \%$ dan uji keefektifan observasi aktivitas belajar dengan presentase $81,25 \%$. Serta adanya uji kelayakan dari validator ahli media dan validator ahli materi. Hasil ini menunjukkan bahwa media pembelajarna yang dikembangkan efektif untuk digunakan dalam menstimulasi siswa tuna grahita di SDN Pandanwangi 3 Malang.
\end{abstract}

\section{ABSTRACT}

Keywords:

mentally disabled

pendet dance motion

cards

This study aims to train the kinesthetic intelligence of mentally disabled students at SDN Pandanwangi 3 Malang. This is done by providing kinesthetic stimulation in the form of Pendet dance basic movements which are explained through the Pendet dance variety motion media. In this media, 3 languages are used, namely Indonesian, English, and Thai. This research using the ADDIE model. Research data sources are mentally disabled students at SDN Pandawangi 3 Malang, GPK, material and media expert validators. The study was conducted twice in the even semester 2018/2019. The research was conducted in 5 stages, namely analysis, design, development, implementation, and evaluation. The results showed (1) implementation of the development of 3 languages based Pendet dance motion cards by conducting teaching and learning processes and the application of 10 basic Pendet dance movements contained in Pendet dance motion cards, (2) the effectiveness of developing dance motion cards 3 languages based pendet as kinesthetic stimulation in mentally disabled children in SDN Pandanwangi 3 Malang must be implemented. This is indicated by the effectiveness test of learning outcomes with a 
percentage of $65 \%$ and the effectiveness test of observing learning activities with a percentage of $81.25 \%$. As well as the due diligence of the media expert validator and material expert validator. These results indicate that the learning media developed are effective for use in stimulating mentally disabled students in SDN Pandanwangi 3 Malang.

(c) Cultural Institute, University of Muhammadiyah Malang, Indonesia

\section{PENDAHULUAN}

Pengetahuan budaya dan pendidikan seni dapat membentuk pribadi anak yang berakhlaq, berbudi pekerti luhur, bermoral dan kreatif. Pembelajaran seni budaya perlu diberikan kepada anak secara langsung untuk membantu mengembangkan aspek kecerdasan dan tumbuh kembang anak, sehingga dapat menjadikan manusia yang utuh sesuai dengan tujuan pendidikan nasional (Wulandari, 2017). Pertumbuhan manusia sering dikaitkan dengan berkembangnya potensi-potensi yang ada pada tubuh seseorang salah satunya fisik, potensi fisik yang berkembang bisa dilihat dari keterampilan gerak dasar yang ditunjukan oleh seseorang. Kecerdasan kinestetik adalah kemampuan individu untuk melakukan sebuah gerakan yang menggunakan gerak anggota seluruh tubuh berupa gerakan kepala, tangan, kaki maupun perut (Yusvarita, 2012). Tari merupakan salah satu cara untuk mengembangkan kecerdasan kinestetik terutama pada anakanak. Dengan menari seseorang dapat mengekpresikan perasaannya melalui tiap gerakan. Kecerdasan kinestetik gerak dasar tari merupakan unsur utama yang mengandung suatu pengertian dan maksud tertentu dari suatu gerak. Minat anak terhadap gerak sangat tinggi karena adanya iringan musik atau lagu- lagu yang dikenal dapat menarik minat anak untuk mengikutinya (Ernawati, 2015).

Pendidikan tari sendiri dapat melatih keterampilan gerak dan kordinasi gerak anak, selain itu sebagai sarana untuk memperkenalkan, membudayakan, menanamkan nilai-nilai seni budaya bangsa. Seni tari sendiri adalah gerak ritmis seni yang menggunakan gerakan tubuh secara berirama untuk keperluan mengungkapkan perasaan, maksud dan pikiran yang dilakukan ditempat dan waktu tertentu (Eki, 2015). Pembelajaran seni tari di sekolah merupakan suatu sarana untuk mengembangkan bakat dan jiwa kreatifitas peserta didik. Pembelajaran seni tari juga dapat mendukung perkembangan motorik gerak pada peserta didik, baik motorik halus maupun motorik kasar.

Pada umumnya perkembangan motorik terbagi menjadi dua bagian yaitu : motorik kasar meliputi duduk, merangkak, berdiri, berjalan, melompat, berlari dan lain-lain. Sedangkan gerak pada motorik halus meliputi memegang mainan, memegang sendok, menggunting, menulis dan sebagainya. Melatih dan mengembangkan gerak pada peserta didik bukanlah suatu hal yang rumit namun bagaiman cara melatih dan mengembangkan motorik pada anak berkebutuhan khusus.

Anak berkebutuhan khusus biasa disebut dengan penyandang disabilitas atau orang-orang yang membutuhkan perlakuan istimewa. Salah satu penyandang disabilitas ialah anak-anak, Menurut data dari Badan Pusat Statistika (BPS) anak-anak penyandang disabilitas atau abk mencapai angka 1,6 juta pada tahun 2018. Menyelamatkan hidup anak-anak berkebutuhan khusus menjadi penting karena dipandang sebagai simbol dari sebuah peradaban yang lebih maju dari suatu bangsa, bahwa penyandang cacat membutuhkan bantuan ekstra (Miriam, 2001). Dunia pendidikan telah mengemas sistem sebaik mungkin terutama untuk anak berkebutuhan khusus. Dengan mengembangkan metode atau media pembelajaran yang dibuat sesuai dengan kebutuhan tiap anak yang tentunya berbeda 
dengan anak normal pada umumnya terutama pada anak tunagrahita.

Anak tunagrahita mengalami keterlambatan perkembangan fungsional seperti: perkembangan sensori terganggu, kognitif atau kecerdasan lebih rendah atau dibawah normal, ingatan mereka lemah, sulit untuk fokus terhadap sesuatu, cepat merasa bosan, kemampuan berbahasa, keterampilan diri, konsep diri, kemampuan berinteraksi sosial, dan juga motorik. Penyandang tuna grahita ringan menunjukan keadaan tubuh yang baik namun bila tidak mendpatakan latihan yang baik memungkinkan akan mengakibatkan postur fisik terlihat kurang sehat (Astuti, 2011).

Hasil analisis kebutuhan berdasarkan observasi dan wawancara pada tanggal 12 Februari 2019 bahwa masih kurangnua media pembelajaran yang digunakan untuk meberikan stimulasi kinestetik pada anak tuna grahita sedangkan siswa tuna grhaita di SDN Pandanwangi 3 Malang membutuhkan media untuk mengembangkan fungsi kecerdasan kinestetik mereka. Oleh sebab itu peneliti ingin melakukan penelitian yang berjudul "Pengembangan Kartu Ragam Gerak Tari Pendet Berbasis 3 Bahasa Sebagai Stimulus Kinestetik pada Anak Tuna Grahita di SDN Pandanwangi 3 Malang". Keunggulan media ini ialah sangat mudah untuk diimplementasikan pada siswa, nyata dan tentunya menarik karena berisikan ragam gerakan tari pendet yang berbeda-beda.

Berikut adalah contoh dari media kartu ragam gerak tari pendet berbasis 3 bahasa sebagai stimulasi pada anak berkebutuhan husus di SDN Pandanwangi 3 Malang.

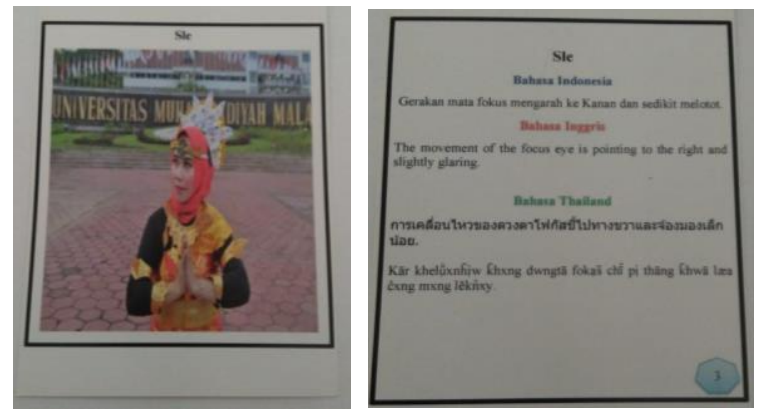

Gambar 1 Tampak Depan (kiri) dan Belakang (kanan) Media (sumber: penulis)
Berdasarkan hal tersebut, tulisan ini bertujuan untuk mengetahui bagaimana pengembangan kartu ragam gerak tari pendet berbasis 3 bahasa sebagai stimulasi kinestetik pada anak tuna grahita di SDN Pandanwangi 3 Malang? dan keefektifan pengembangan kartu ragam gerak tari pendet berbasis 3 bahasa sebagai stimulasi kinestetik pada anak tuna grahita di SDN Pandanwangi 3 Malang harus diterapkan?

\section{METODE}

Jenis penelitian yang digunakan adalah penelitian dan pengembangan. Model yang digunakan yaitu menggunakan model ADDIE. Model ini terdiri dari lima tahapan, yaitu analisis, desain, pengembangan, implementasi, dan evaluasi. Penelitian dilakukan di SDN Pandanwangi 3 Malang pada tanggal 17 dan 19 Juni 2019. Teknik pengumpulan data yaitu menggunakan observasi, wawancara, dan dokumentasi. Teknik analisis data yang digunakan pada penelitian ini menggunakan teknik analisis data deskriptif kualitatif dan analisis data kuantitatif.

\section{HASIL DAN PEMBAHASAN}

Penelitian ini dilaksanakan dengan menggunakan model ADDIE, dengan tahapan-tahapannya yaitu analisis, desain, pengembangan, implementasi dan evaluasi. Berikut paparan hasil penelitian yang dilakukan.

\section{Analisis}

Tahap analisis ini dilakukan dengan wawancara dan observasi pada tanggal 13 Februari 2019 di SDN Pandanwangi 3 Malang. Wawancara dilakukan dengan GPK (Guru Pendamping Khusus) dan siswa tuna grahita di SDN Pandanwangi 3 Malang. Melalui hal ini dapat dilihat permasalahan yang terdapat di sekolah. Berdasarkan wawancara dengan GPK diperoleh hasil bahwa masih minimnya media pembelajaran yang digunakan untuk mengembangkan fungsi kecerdasan kinestetik pada anak tuna grahita di sekolah ini. 


\section{Desain}

Tahap desain atau perencanaan media adalah tahap yang dilakukan setelah melakukan analisis. Pada tahap ini peneliti menentukan media yang akan dikembangkan berdasarkan analisis kebutuhan siswa tuna grahita di SDN Pandanwangi 3 Malang. Tahap awal peneliti merancang desain kartu ragam gerak tari pendet berbasis 3 bahasa sebagai stimulasi kinestetik pada anak tuna grahita, menentukan materi, memilih 10 gerakan dasar tari pendet, alat dan bahan yang akan digunakan dalam proses pembuatan media kartu ragam gerak tari pendet, yaitu menggunakan kertas art paper.

\section{Pengembangan}

Tahap pengembangan media pembelajaran kartu ragam gerak tari pendet berbasis 3 bahasa sebagai stimulasi kinestetik pada anak tuna grahita di SDN Pandanwangi 3 Malang ini dilakukan dalam dua tahapan, yaitu desain dan konten. Tahapan desain merupakan bentuk pengelolaan rancangan menjadi sebuah produk sedangkan pada tahap konten melakukan validasi materi dan media kepada validator. Hasil yang didapatkan saat uji validasi materi yang pertama menunjukan presentase $75 \%$ dan setelah di revisi menunjukan presentase $100 \%$, sedangkan pada uji validasi media yang pertama menunjukan presentase $83,3 \%$ dan setelah di revisi menunjukan presentase $92,8 \%$. Melalui uji validasi dan presentase yang ditunjukan dapat disimpulkan bahwa media valid sangat layak digunakan bagi siswa tuna grahitadi SDN Pandanwangi 3 Malang.

\section{Implementasi}

Tahap implementasi adalah tahap untuk menerapkan atau mengujicobakan media pembelajaran kartu ragam gerak tari pendet berbasis 3 bahasa sebagai stimulasi kinestetik pada anak tuna grahita di SDN Pandanwangi 3 Malang yang telah di validasi oleh validator ahli materi dan ahli. Implementasi dilakukan 2 kali pada tanggal 17 Juni dan 19 Juni 2019 dengan jumlah 2 orang siswa tuna grahita. Pada tahap ini proses pembelajaran dilakukan kepada siswa tuna grahita.

Siswa dikenalkan 10 gerakan dasar tari pendet melalui media kartu ragam gerak tari pendet. Dalam proses implementasi, peneliti melihat dari hasil observasi aktivitas belajar peserta didik dengan presentase $81,25 \%$ dan ditinjau dari data hasil belajar peserta didik dengan presentase $65 \%$ dapat diartikan bahwa media efektif digunakan untuk memberikan stimulasi kinestetik agar fungsi kecerdasan kinestetiknya dapat berkembang dengan baik.

\section{Evaluasi}

Tahap evaluasi pada pengembangan media pembelajaran kartu ragam gerak tari pendet berbasis 3 bahasa sebagai stimulasi kinestetik pada anak tuna grahita di SDN Pandanwangi 3 Malang dilakukan dari tahap analisis sampai dengan tahap implementasi. Evaluasi dilakukan untuk mengevaluasi proses implementasi dan keefektifan media kartu ragam gerak tari pendet berbasis 3 bahasa sebagai stimulasi kinestetik pada anak tuna grahita di SDN Pandanwangi 3 Malang.

\section{KESIMPULAN}

Berdasarkan hasil penelitian yang telah dilakukan, hasil validasi media ahli materi menunjukan presentase $100 \%$ sedangkan hasil presentase dari ahli media menunjukan presentase $92,8 \%$ dapat disimpulkan bahwa materi sangat valid dan untuk digunakan. Melalui implementasi yang dilakukan dapat diketahui dengan melakukan uji efektifitas yang dilihat dari dua aspek dilihat dari hasil observasi aktivitas belajar peserta didik dengan presentase $81,25 \%$ dan ditinjau dari data hasil belajar peserta didik dengan presentase $65 \%$ dapat diartikan bahwa media efektif digunakan untuk memberikan stimulasi kinestetik agar fungsi kecerdasan kinestetiknya dapat berkembang dengan baik.

Melalui penilaian tersebut dapat disimpulkan bahwa media kartu ragam gerak tari pendet berbasis 3 bahasa sebagai 
stimulasi kinestetik pada anak tuna grahita di SDN Pandanwangi 3 Malang yang dikembangkan valid dan efektif untuk digunakan pada siswa tuna grahita di SDN Pandanwangi 3 Malang.

\section{REFERENSI}

Ardy, N. W. (2014). Buku Ajar Penanganan Anak Usia Dini Berkebutuhan Khusus. Yogyakarta: Ar-Ruzz Media.

Choirunnisa, F. (2017). Analisis Pelaksanaan Ekstrakurikuler Seni Tari Tradisional pada Gerak Motorik Anak Tuna Grahita di SLB Sumber Dharma Malang. Skripsi tidak Diterbitkan. Malang: Universitas Muhammadiyah Malang.

Elaine B. Frankel (2004) Supporting Inclusive Care and Education for Young Children with Special Needs and Their Families an International Perspective, Childhood Education, 80:6, 310-316.

Gunawan, D. (2016). Pengembangan Keterampilan Gerak Dasar Motorik Kasar Melalui Pembelajaran Seni Tari Kipas pada Anak Tunarungu. Jurnal Penelitian Pendidikan, 16(1).

Kustiatun, W. (2018). Mereka yang Istimewa yang Berkarya: Pelayanan Anak Berkebutuhan Khusus untuk Mengembangkan Potensinya. Malang: Pustaka Media Guru.

Ramadhan, M. (2013). Ayo Belajar Mandiri Pendidikan Keterampilan dan Kecakapan Hidup untuk Anak Berkebutuhan Khusus. Yogyakarta. Javalitera.

Sugiono. (2013). Metode Penelitian Kuantitatif, Kualitatif, dan $R \& D$. Bandung: Alfabeta.

Tegeh, M dkk. (2014). Model Penelitian Pengembangan. Jogjakarta: Graha Ilmu. 